\title{
Primary duodenal mucosa-associated lymphoid tissue (MALT) lymphoma - A rare presentation of gastric outlet obstruction
}

\author{
Tamar Tadmor MD1, Tova Rainis $\mathrm{MD}^{1}$, Jacob Bejar $\mathrm{MD}^{2}$, Dina Attias MD ${ }^{3}$, Alexandra Lavy $\mathrm{MD}^{1}$
}

T Tadmor, T Rainis, J Bejar, D Attias, A Lavy. Primary duodenal mucosa-associated lymphoid tissue (MALT) lymphoma - A rare presentation of gastric outlet obstruction. Can J Gastroenterol 2007;21(6):393-395.

Malignant lymphoma of mucosa-associated lymphoid tissue (MALT) can arise in a variety of anatomical sites. The majority of these tumors arise in the stomach, with fewer than 30\% arising in the small intestine. Primary duodenal MALT lymphoma is a very rare neoplasm. There are very few cases of duodenal MALT lymphoma reported in the literature. This is the third published case presenting clinically as a gastric outlet obstruction. The patient was successfully treated with a combination of chemotherapy and rituximab.

Key Words: Gastric outlet obstruction; MALT lymphoma; Rituximab alignant lymphoma of mucosa-associated lymphoid tissue (MALT) has been recognized since the early 1980s as a distinct clinical and pathological entity that can arise in a variety of anatomical sites (1-3). The majority of these tumours arise in the stomach, with fewer than 30\% arising in the small intestine $(4,5)$. Primary duodenal MALT lymphoma is a very rare neoplasm $(2-3,6-9)$. There are very few cases of duodenal MALT lymphoma reported in the literature. This is the third published case presenting clinically as a gastric outlet obstruction. The patient was successfully treated with a combination of chemotherapy and rituximab (a monoclonal antibody specific to CD20).

\section{CASE PRESENTATION}

A previously healthy 52-year-old woman was admitted with severe nausea, intractable vomiting and progressive weight loss of approximately $15 \mathrm{~kg}$. Except for signs of cachexia, her physical examination was normal. Routine hematology and biochemistry tests were also normal. An abdominal computed tomography scan demonstrated a large mass, $7 \mathrm{~cm} \times 5 \mathrm{~cm} \times 5 \mathrm{~cm}$, in the third part of the duodenum (Figure 1). Upper endoscopy demonstrated a normal gastric mucosa, and massive infiltration and narrowing of the duodenum (Figure 2). Histological examination of the stomach was normal and negative for Helicobacter pylori. Histology of the duodenal infiltration was compatible with MALT lymphoma: presence of lymphoepithelial lesions with a monoclonal population positive for CD19, CD20 and
Lymphome primitif duodénal du système lymphoïde des muqueuses : cas rare d'obstruction de l'orifice de sortie de l'estomac

\begin{abstract}
Le lymphome malin du système lymphoïde des muqueuses (MALT) peut prendre naissance en divers points de l'organisme. Il se développe généralement dans l'estomac, et moins de $30 \%$ des tumeurs naissent dans l'intestin grêle. Le lymphome primitif duodénal de type MALT s'observe très rarement, et la documentation ne fait état que de très peu de cas. Il s'agit, en fait, du troisième cas publié, se manifestant sous forme d'obstruction clinique de l'orifice de sortie de l'estomac. Le patient a été traité avec succès par la chimiothérapie et au rituximab
\end{abstract}

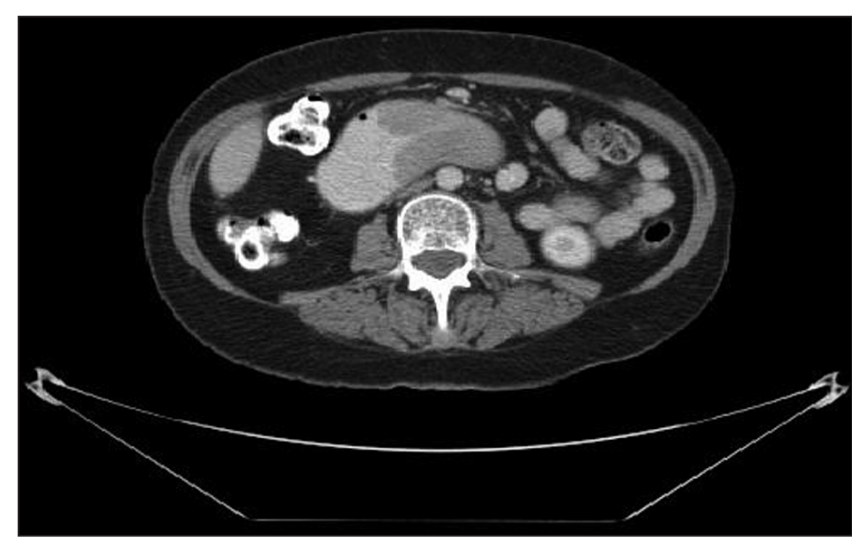

Figure 1) Computed tomography scan of abdomen, demonstrating a large mass in the third part of the duodenum

CD22, and negative for CD5, CD10, CD3 and cyclin D1 (Figure 3). Her bone marrow examination was also normal.

The patient was diagnosed as having stage EII MALT lymphoma.

Chemotherapy with chlorambucil, prednisone and rituximab (monoclonal antibody-specific CD20) was initiated.

The response was prompt, and shortly after the first cycle of therapy, the patient had no further obstructive symptoms and started gaining weight.

\footnotetext{
${ }^{1}$ Gastroenterology Unit; ${ }^{2}$ Pathology Unit; ${ }^{3}$ Hematology Unit, Bnai-Zion Medical Center, Haifa, Israel

Correspondence: Dr Tova Rainis, Gastroenterology Unit, Bnai-Zion Medical Center, Golomb Street, Haifa, 31048 Israel.

Telephone 972-544-55-0002, fax 972-777-11-0311,e-mail tova@4utv.co.il

Received for publication March 14, 2006. Accepted July 17, 2006
} 


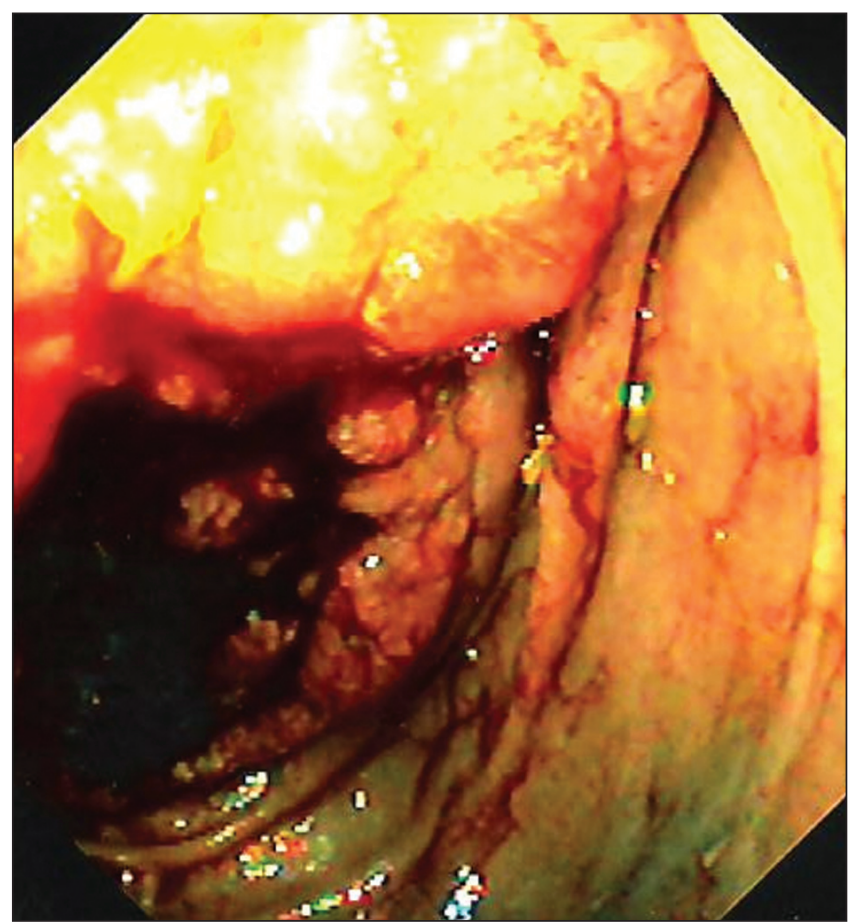

Figure 2) Endoscopic view of a malignant stricture involving the third part of the duodenum

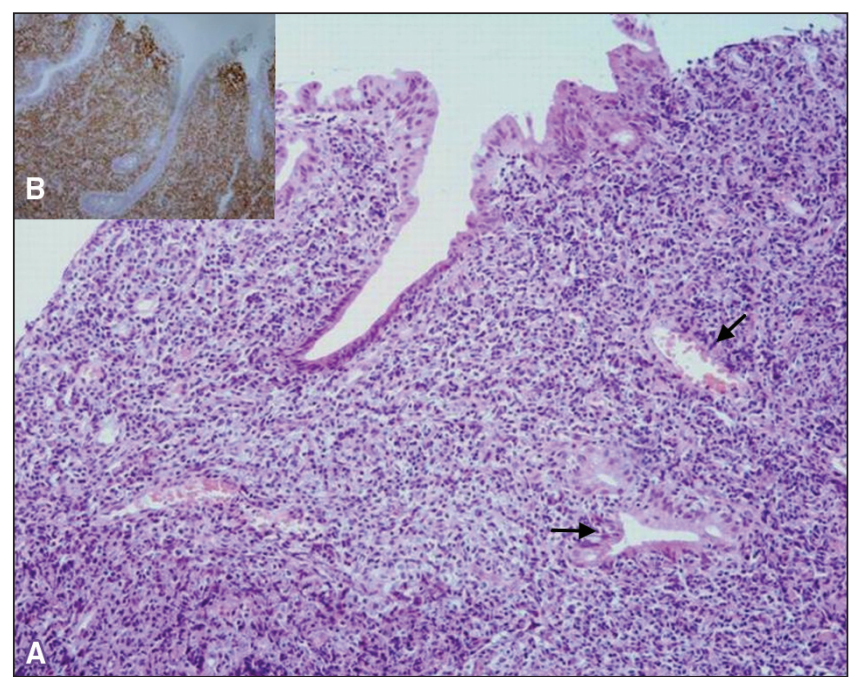

Figure 3) A Photomicrograph showing diffuse lymphoid infiltration associated with lymphoepithelial lesions (arrows) (hematoxylin and eosin stain, original magnification $\times 100$ ). B Photomicrograph showing virtually all atypical-appearing lymphoid cells expressing the B cellassociated antigen CD20 (immunohistochemical stain, original magnification $\times 100$ )

After one cycle of chemotherapy, the abdominal computed tomography scan showed $50 \%$ regression of the mass; a positron emission tomography - fluorodeoxyglucose scan after three months of therapy showed no evidence of the disease. Follow-up endoscopy six months after resolution of therapy was normal (Figure 4).

\section{DISCUSSION}

Primary lymphoma of the digestive tract accounts for $4.5 \%$ of all lymphomas $(10,11)$. MALT lymphoma, first described

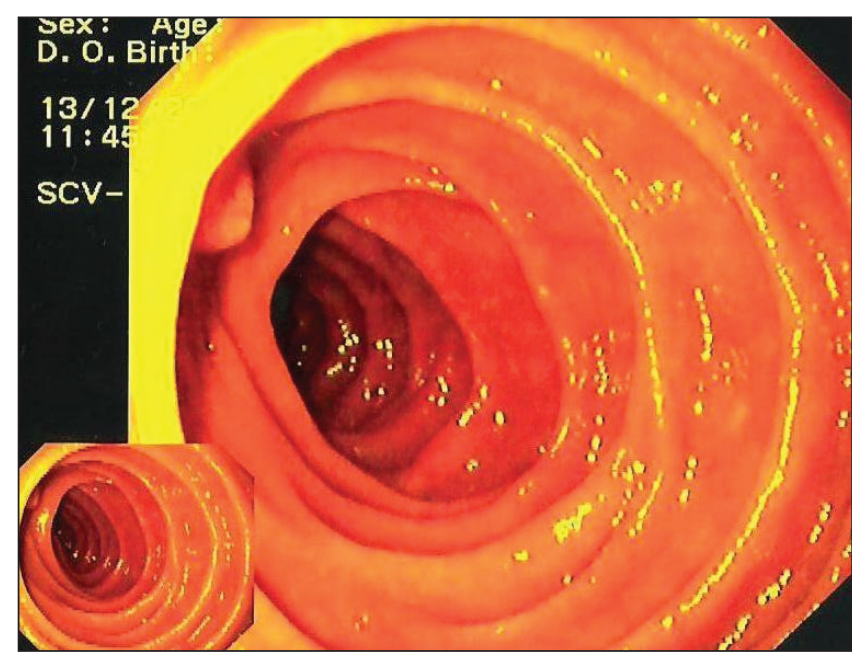

Figure 4) Endoscopic view after resolution of therapy showing no evidence of a mass in the duodenum

by Isaacson and Wright (3), comprises 7\% to $8 \%$ of all B cell lymphomas (12). MALT lymphoma is characterized by diffuse infiltration of the lamina propria by 'centrocyte-like' cells, and is associated with lymphoid follicles and lymphoepithelial lesions. The gastrointestinal tract is the most common site of MALT lymphomas, while the stomach is the most common location $(4,5,10)$.

Primary duodenal MALT lymphoma represents a very rare neoplasm. Little is known of the presenting manifestations, natural course or treatment of duodenal MALT lymphoma, due to its rarity (2).

$H$ pylori infection has been associated with gastric MALT lymphomas $(13,14)$. The role of $H$ pylori in duodenal MALT lymphoma is unclear. Therapy of $\mathrm{H}$ pylori infection has been correlated with tumour regression $(6,15)$. Nagashima et al (6) reported regression of duodenal MALT lymphoma following eradication of $H$ pylori. In our case, $H$ pylori was negative.

Treatment of upper outlet obstruction due to low-grade MALT lymphoma has not yet been standardized. Most investigators recommend surgery, arguing that it is the best way to eradicate a localized and obstructing process (16). Being a mutilating procedure, surgery was considered too aggressive for our patient who presented with a low-grade MALT lymphoma.

Lepicard et al (17) reported four cases of duodenal MALT lymphoma treated with cyclophosphamide, which induced complete remission.

The use of rituximab in combination with chemotherapy has been evaluated as safe and active for the treatment of nonHodgkin lymphoma, resulting in a significant increase in remission rates $(18,19)$. Recently, Martinelli et al (20) confirmed that the use of rituximab is a very effective modality of treatment in gastric MALT lymphoma.

Our patient was treated with a combination of chlorambucil, prednisone and rituximab. She responded rapidly to the treatment and achieved complete remission. To the best of our knowledge, this is the first case of a duodenal MALT lymphoma treated successfully with rituximab in combination with chemotherapy.

\section{CONCLUSION}

MALT lymphoma of the duodenum is poorly characterized due to its rarity, and optimal treatment has not been elucidated. 
The prognosis of duodenal low-grade MALT lymphoma is relatively good, and prolonged survival is possible with chemotherapy. The combination therapy of chlorambucil, prednisone and rituximab was well tolerated, active in inducing complete remission and avoiding mutilating surgery. The addition of rituximab to conventional chemotherapy may contribute to the significant positive response and length of remission. Further studies evaluating the use of rituximab alone or in combination with chemotherapy are warranted to define the best modality of treatment.

\section{REFERENCES}

1. Isaacson PG, Spencer J. Malignant lymphoma of mucosa-associated lymphoid tissue. Histopathology 1987;11:445-62.

2. Wang HH, Lin JT, Chiu CC, Chiang IP, Wu MS, Wang TH. Endoscopic features of mucosa-associated lymphoid tissue lymphoma of the duodenum. Gastrointest Endosc 1995;41:258-61.

3. Isaacson P, Wright DH. Malignant lymphoma of mucosa-associated lymphoid tissue. A distinctive type of B-cell lymphoma. Cancer 1983;52:1410-6.

4. Dragosics B, Bauer P, Radaszkiewiez T. Primary gastrointestinal non-Hodgkin's lymphomas. A retrospective clinicopathologic study of 150 cases. Cancer 1985;55:1060-73.

5. Aozasa K, Ueda T, Kurata A, et al. Prognostic value of histologic and clinical factors in 56 patients with gastrointestinal lymphomas. Cancer 1988;61:309-15.

6. Nagashima R, Takeda H, Maeda K, Ohno S, Takahashi T. Regression of duodenal mucosa-associated lymphoid tissue lymphoma after eradication of Helicobacter pylori. Gastroenterology 1996;111:1674-8.

7. Tsuji K, Katanuma A, Mori M, et al. Clinical study of MALT lymphomas and related diseases of the duodenum representing characteristic findings. Gastroenterol Endosc 1996;38:1931.

8. Yoshida T, Lesato Y, Yokomori T, et al. A case of primary MALT lymphoma of the duodenum. Jpn J Gastroenterol Surg 1966;29:452.
9. Leone N, Brunello F, Baronio M, et al. High grade B-cell lymphoma arising in mucosa-associated lymphoid tissue of the duodenum. Eur J Gastroenterol Hepatol 2002;14:893-6.

10. Radaszkiewiez T, Dragosics B, Bauer P. Gastrointestinal malignant lymphoma of the mucosa-associated lymphoid tissue: Factors relevant to prognosis. Gastroenterology 1992;102:1628-38.

11. Najem AZ, Porcaro JL, Rush BF Jr. Primary non-Hodgkin's lymphoma of the duodenum. Case report and literature review. Cancer 1984;54:895-8.

12. A clinical evaluation of the International Lymphoma Study Group classification of non-Hodgkin's lymphoma. The Non-Hodgkin's Lymphoma Classification Project. Blood 1997;89:3909-18.

13. Eidt S, Stolte M, Fischer R. Helicobacter pylori gastritis and primary gastric non-Hodgkin's lymphomas. J Clin Pathol 1994;47:436-9.

14. Wotherspoon AC, Ortiz-Hidalgo C, Falzon MR, Isaacson PG. Helicobacter pylori-associated gastritis and primary B-cell gastric lymphoma. Lancet 1991;338:1175-6.

15. Bayerdorffer E, Neubauer A, Rudolph B, et al. Regression of primary gastric lymphoma of mucosa-associated lymphoid tissue type after cure of Helicobacter pylori infection. MALT Lymphoma Study Group. Lancet 1995;345:1591-4.

16. Ruskone-Fourmestraux A, Aegerter P, Delmer A, Brousse N, Galian A, Rambaud JC. Primary digestive tract lymphoma: A prospective multicentric study of 91 patients. Groupe d'Etude des Lymphomes Digestifs. Gastroenterology 1993;105:1662-71.

17. Lepicard A, Lamarque D, Levy M, et al. Duodenal mucosa-associated lymphoid tissue lymphoma: Treatment with oral cyclophosphamide. Am J Gastroenterol 2000;95:536-9.

18. Coiffier B, Lepage E, Briere J, et al. CHOP chemotherapy plus rituximab compared with CHOP alone in elderly patients with diffuse large-B-cell lymphoma. N Engl J Med 2002;346:235-42.

19. Martinelli G, Laszlo D, Bertolini F, et al. Chlorambucil in combination with induction and maintenance rituximab is feasible and active in indolent non-Hodgkin's lymphoma. Br J Haematol 2003;123:271-7.

20. Martinelli G, Laszlo D, Ferreri AJ, et al. Clinical activity of rituximab in gastric marginal zone non-Hodgkin's lymphoma resistant to or not eligible for anti-Helicobacter pylori therapy. J Clin Oncol 2005;23:1979-83. 


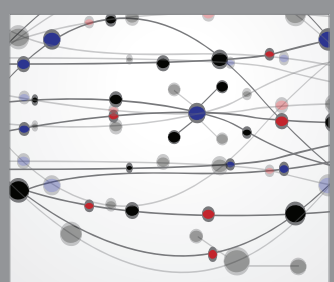

The Scientific World Journal
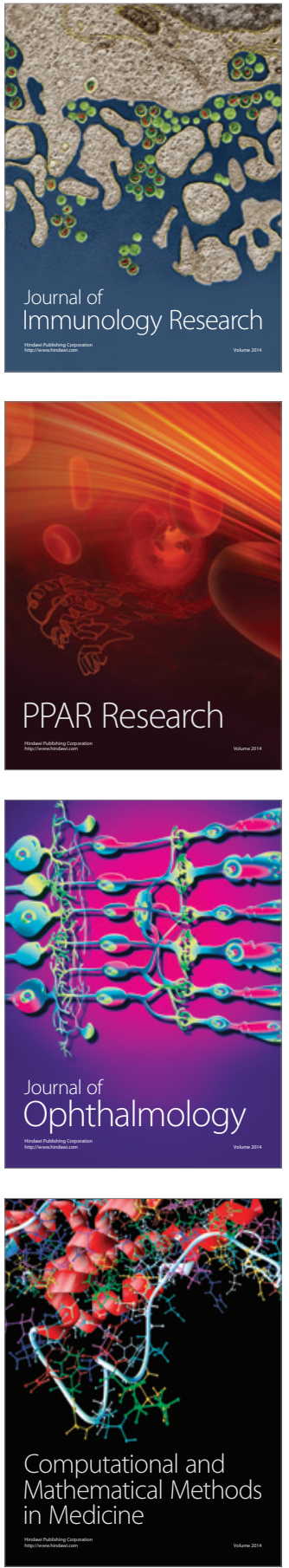

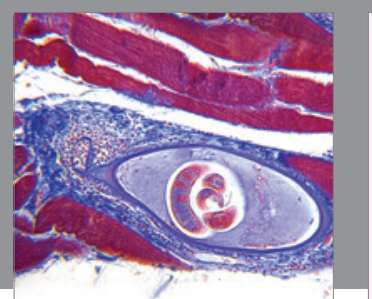

Gastroenterology Research and Practice

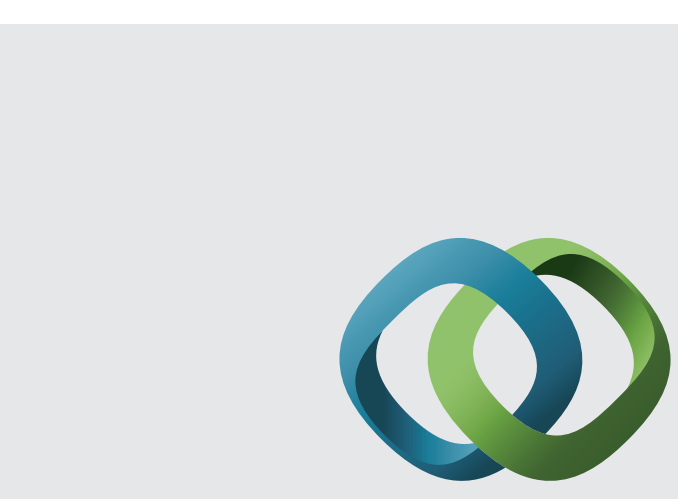

\section{Hindawi}

Submit your manuscripts at

http://www.hindawi.com
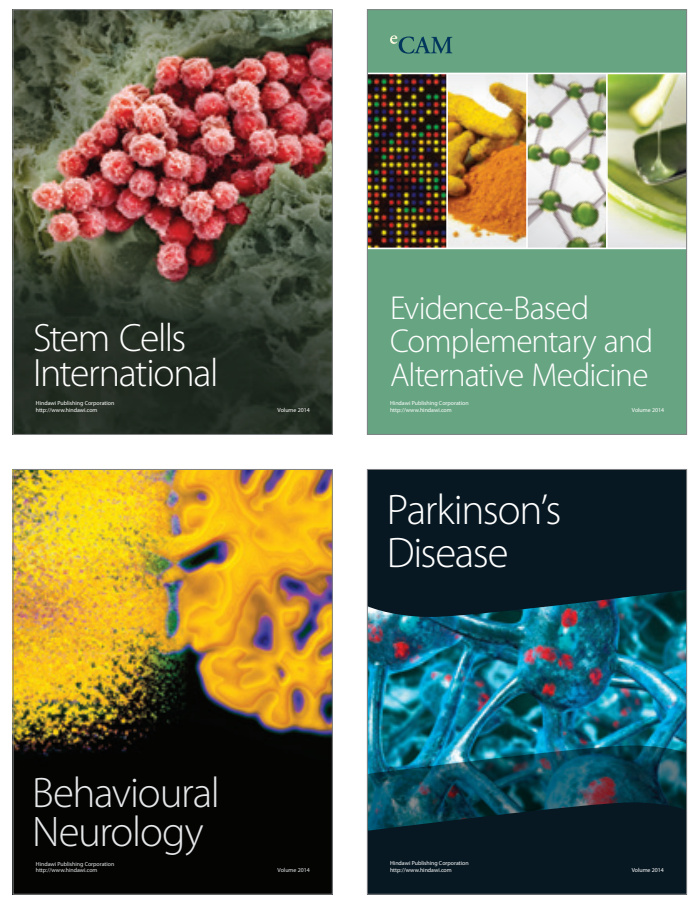
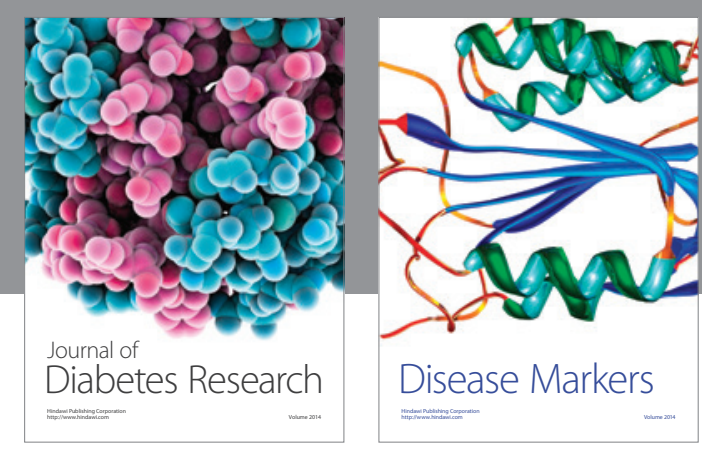

Disease Markers
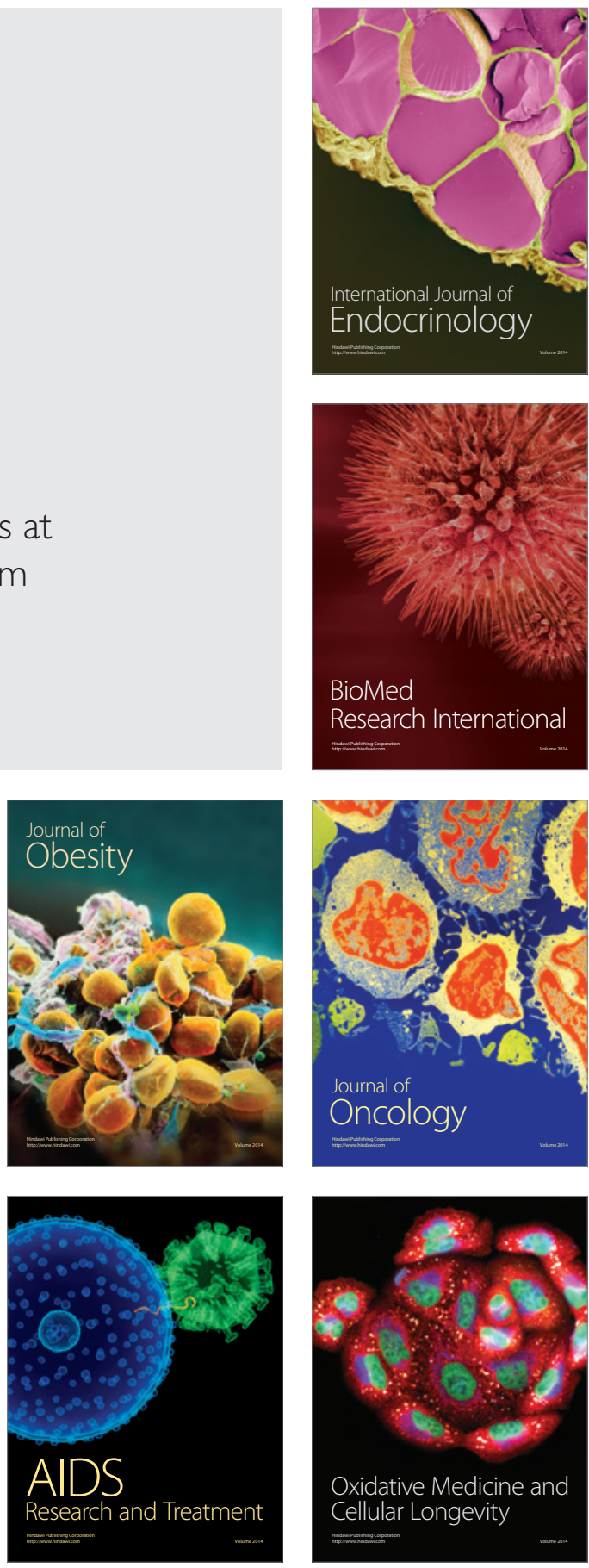